\title{
Enforcement of EU agri-food law
}

\section{Regulation (EU) 2017/625 on official controls and other official activities performed to ensure the application of food and feed law, rules on animal health and welfare, plant health and plant protection products}

\author{
Bernd M.J. van der Meulen ${ }^{1}$
}

Published online: 12 November 2018

(C) The Author(s) 2018

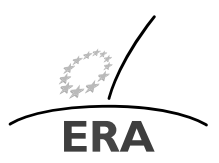

EUROPÄISCHE RECHTSAKADEMIE ACADEMY OF EUROPEAN LAW ACADEMIE DE DROIT EUROPEEN ACCADEMIA DI DIRITTO EUROPEO TRIER - TREVES - TREVIRI

\begin{abstract}
A new Official Controls Regulation comes into force in the agri-food sector of the EU. This article analyses the Regulation from the perspective of the various stakeholders. It appears that the Regulation is mainly instrumental in nature. It provides a toolbox to competent authorities in the Member States. Instruments are provided for inspection and to rectify non-compliances. It is weaker in providing checks and balances to food businesses. It does protect whistle-blowers. Empowerment of victims and consumers is totally absent.
\end{abstract}

Keywords Food Law Enforcement · Official controls · Enforcement measures · Penalties

\section{Introduction}

\subsection{Approach}

From 14 December 2019 onwards, a new Regulation on official controls will apply in EU food law. In this article I will discuss this new Regulation, Regulation (EU)

Prof. Dr. B.M.J. van der Meulen (www.BerndvanderMeulen.eu) is director of the European Institute for Food Law (www.food-law.nl), professor of Food Law at Wageningen University in the Netherlands and of Comparative Food Law at Renmin School of Law (Renmin University, Beijing, China) under the 'Program of Top-level Foreign Experts of the State Administration of Foreign Experts Affairs of the People's Republic of China'.

This article elaborates on a presentation of the author at the 2018 ERA conference on food law in Brussels. A recording of this presentation is available via: https://www.berndvandermeulen.eu/speeches.html

Prof. Dr. B.M.J. van der Meulen

Bernd.vanderMeulen@food-law.nl

1 Wageningen University, Wageningen, The Netherlands 
Fig. 1 Enforcement relations

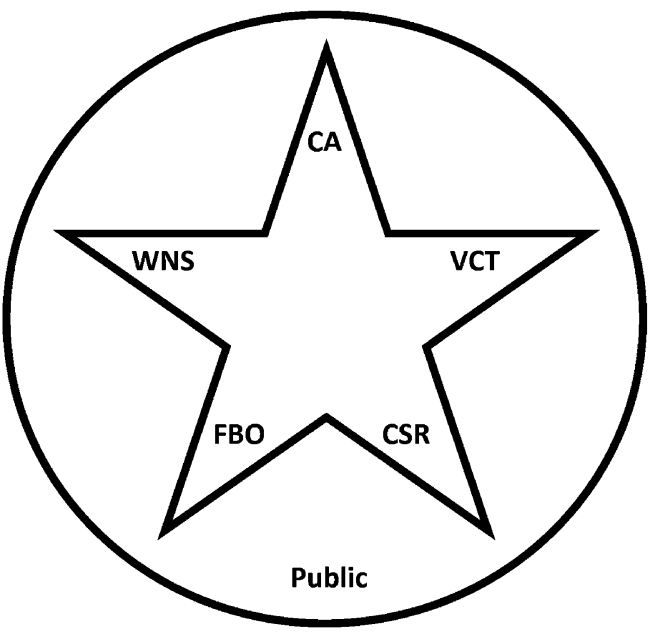

$2017 / 625$ [11], ${ }^{1}$ from the perspectives of the different stakeholders involved. In my view such perspectives help to highlight stronger and weaker points in the Regulation and to identify gaps.

Enforcement is often perceived as involving two parties: perpetrators and authorities. I will use a slightly more nuanced picture as illustrated in Fig. 1.

This figure has been built on the assumption that EU food law mainly addresses food business operators (FBOs). The obligation to comply is on these addressees. Where non-compliance occurs, often there will be victims (VCT). Much of EU food law aims to protect the interests of the consumer. Therefore, the consumer stands out as interested party (CSR). Particularly among the consumers, victims of food safety infringements can be found. Other victims may include businesses suffering from unfair competition by perpetrators. All these are potentially included in the category VCT in the figure. However, law enforcement is also considered to be in the general interest of the public. This general interest is represented by the outside circle. The general public includes consumers, both victims and other consumers, but also citizens, ${ }^{2}$ NGOs and corporate entities. The general public will not be further ad-

\footnotetext{
${ }^{1}$ Regulation (EU) 2017/625 of the European Parliament and of the Council of 15 March 2017 on official controls and other official activities performed to ensure the application of food and feed law, rules on animal health and welfare, plant health and plant protection products, amending Regulations (EC) No 999/2001, (EC) No 396/2005, (EC) No 1069/2009, (EC) No 1107/2009, (EU) No 1151/2012, (EU) No 652/2014, (EU) 2016/429 and (EU) 2016/2031 of the European Parliament and of the Council, Council Regulations (EC) No 1/2005 and (EC) No 1099/2009 and Council Directives 98/58/EC, 1999/74/EC, 2007/43/EC, 2008/119/EC and 2008/120/EC, and repealing Regulations (EC) No 854/2004 and (EC) No 882/2004 of the European Parliament and of the Council, Council Directives 89/608/EEC, 89/662/EEC, 90/425/EEC, 91/496/EEC, 96/23/EC, 96/93/EC and 97/78/EC and Council Decision 92/438/EEC (Official Controls Regulation) [2017] OJ L 95/1.

I will refer to this Regulation as NOCR (New Official Controls Regulation).

At many instances, I closely follow the text of the Regulation, but not always word-perfect, therefore not always using quotation marks.

${ }^{2}$ The words 'consumer' and 'citizen' refer to the same people but in different roles. Consumers perform economic roles while citizens perform political roles such as voting. The distinction between the two
} 
dressed in this article. Enforcement is performed by competent authorities (CA). The CA may need to rely on information from third parties. In Fig. 1, these third parties are called witnesses (WNS). Witnesses can be the FBO itself, victims, consumers but also employees of the FBO or others. The categories of stakeholders identified in the figure are therefore not mutually exclusive. ${ }^{3}$ The CA stands in relation to all other stakeholders in the figure, and most of these among each other as well.

\subsection{Organisation of the article}

This article is organised as follows. Section 2 addresses the motive for and scope of the new Regulation. Section 3 introduces the powers provided to competent authorities. This is by far the largest section of this article. This reflects the instrumental nature of the Regulation. It places emphasis on public powers. Section 4 discusses the position of business operators as subject of official controls in terms of their obligations and rights. Sections 5 and 6 set out the position of witnesses and victims respectively. Consumers in general are discussed together with victims. Section 7 introduces a few special topics. These special topics overlap issues discussed earlier in the article, presenting them from a different perspective. The article concludes with my personal opinions as a basis for discussion in Sect. 8.

There are many elements in the Regulation ${ }^{4}$ that cannot be discussed within the space limits of this article; such as institutional aspects, confidentiality, transparency, supervision of national controls by the European Commission, ${ }^{5}$ information management and cross-border controls. ${ }^{6}$

\section{Why a new Regulation on Official Controls?}

\subsection{Motives}

The current Official Controls Regulation (Regulation 882/2004 on official controls $[10])^{7}$ is still relatively young. No evaluation showed major shortcomings requiring a total recast. Instead, what we are witnessing seems to be a stealthy codification at EU level of the law on administrative enforcement in the Member States. The most important change is a considerable expansion of the scope of the official controls regulation from only food law to now covering almost the entire agri-food sector. With

\footnotetext{
concepts can be helpful for example when people appear to set different priorities in the public debate and in their private shopping behaviour.

${ }^{3}$ Further distinctions may be considered for the future. Competent authorities performing controls are not necessarily the same as authorities taking measures or imposing sanctions. Business operators subject to official controls in general may be distinguished from operators suspected of having committed infringements or even found guilty of infringements.

${ }^{4}$ See on some of these topics: Corini [2]. See also her article in this issue.

${ }^{5}$ On this topic see for example, Corini et al. [3].

${ }^{6}$ On this topic see for example, Hyde/Savage [5] and Van der Meulen/Corini [16].

${ }^{7}$ Regulation (EC) No 882/2004 [10].
} 
the new regulation, an elaborate system, including supervision by the European Commission, applies to sectors previously not harmonised with regard to enforcement.

The Regulation itself, in Recitals 19 and 99, expresses it as follows:

'In order to rationalise and simplify the overall legislative framework, whilst simultaneously pursuing the objective of better regulation, the rules applicable to official controls in specific areas should be integrated into a single legislative framework for official controls. ${ }^{, 8}$

'[T]he objective of this Regulation, [is] to ensure a harmonised approach with regard to official controls and other official activities performed in view of ensuring the application of Union agri-food chain legislation'.

Among the modernisations introduced by the new Regulation is the awareness of increasing online trade. ${ }^{10}$ See here below, Sect. 3.5.

While the legislative process was already underway, the horsemeat scandal erupted. For reasons difficult to fathom, this scandal - unlike previous ones - sparked awareness of fraud as an issue the legislation must address. Some provisions to this effect have been included. See Sect. 7.1.

\subsection{Scope}

The major issue, therefore, is the expanded scope of the Official Controls Regulation. According to Article 1(2), the NOCR [11] covers official controls performed for the verification of compliance with the rules, whether established at Union level or by the Member States, to apply Union legislation, in the areas of food and food safety; integrity and wholesomeness; deliberate release into the environment of genetically modified organisms (GMOs) for food or feed; food and feed safety; animal health; animal by-products; animal welfare; plant pests; plant protection products; organics; and protected designations.

Now that the scope is widened beyond food law proper, the range of addressees is also no longer limited to food business operators (FBOs). The terminology the new Regulation uses for the addressees is now simply: business operators (BOs).

\section{Competent authorities}

\subsection{Elements of enforcement}

The Official Controls Regulation defines official controls as:

'activities performed by the competent authorities, or by the delegated bodies or the natural persons to which certain official control tasks have been delegated in accordance with this Regulation, in order to verify:

\footnotetext{
${ }^{8}$ Recital 19 NOCR [11].

${ }^{9}$ Recital 99 NOCR [11].

${ }^{10}$ See for the effects of online trade in food on contract law and product liability, Van der Veer [25].
} 
(a) compliance by the operators with this Regulation and with the rules referred to $[\ldots]$; and

(b) that animals or goods meet the requirements laid down in the rules referred to [...], including for the issuance of an official certificate or official attestation.'

While official controls is the main topic of the new Official Controls Regulation, the Regulation covers enforcement in a wider sense.

We may observe three consecutive enforcement steps in the Regulation: 1) official controls to verify compliance; 2) investigation in case of a suspicion of noncompliance, and 3) actions to be taken when non-compliance is established. In addition to this, the NOCR [11] addresses penalties and Union enforcement measures. ${ }^{11}$

\subsection{Risk based official controls}

Article 9 NOCR [11] gives general rules on official controls. These general rules imply that a policy on official controls has to be in place. According to this provision, competent authorities shall perform official controls on all operators regularly, on a risk basis and with appropriate frequency.

The concept 'risk basis' is important in this context. The Regulation includes a definition of 'risk'. ${ }^{12}$ According to this definition, 'risk' means a function of the probability of an adverse effect on human, animal or plant health, animal welfare or the environment and of the severity of that effect, consequential to a hazard. The concept of hazard is also defined: 'hazard' means any agent or condition with the potential to have an adverse effect on human, animal or plant health, animal welfare or the environment. ${ }^{13}$ These definitions sound familiar. They are completely in line with the definitions in the General Food Law. ${ }^{14}$ However, in the General Food Law these definitions function in the context of risk analysis as methodology for underpinning food legislation. They are strongly related to characteristics and conditions of products. It is less evident that these definitions are suitable in the context of policies on official controls.

According to Article 9 NOCR [11], official controls must be performed taking account of identified risks associated with, among others, goods, activities, location, products and processes, but also any information indicating the likelihood that consumers might be misled, in particular as to the nature, identity, properties, composition, quantity, durability, country of origin or place of provenance, method of manufacture or production of food; operators' past record of compliance; the reliability and results of own controls that have been performed by the operators, or by a third party at their request, including, where appropriate, private quality assurance schemes; and, any information that might indicate non-compliance. Official controls should aim to

\footnotetext{
${ }^{11}$ Art. 141 NOCR [11].

${ }^{12}$ Art. 3(24) NOCR [11].

${ }^{13}$ Art. 3(23) NOCR [11].

${ }^{14}$ Regulation (EC) No 178/2002 of the European Parliament and of the Council of 28 January 2002 laying down the general principles and requirements of food law, establishing the European Food Safety Authority and laying down procedures in matters of food safety [2002] OJ L 31/1 [8].
} 
identify possible intentional violations perpetrated through fraudulent or deceptive practices.

It is clear that the elements of a risk-based policy on official controls go far beyond the risk to health as suggested by the definition in the Regulation. The Regulation rather seems to have in mind the likelihood that non-compliance will take place rather than only the risk for health. Therefore, including the definition of 'risk' at best is only partly helpful in understanding the notion of 'risk based' official controls. At worst it is confusing.

Article 9 NOCR [11] further indicates that official controls should be performed without prior notice, except when duly justified. Such justification could, for example, occur when official controls require the presence of certain staff members, like when the functioning of safety assurance systems is controlled.

Official controls should be performed as much as possible in such a manner that the administrative burden and operational disruption for operators are kept to the minimum necessary, but without this negatively affecting the effectiveness of those controls. $^{15}$

\subsection{Instruments for official controls}

The NOCR [11] attributes control powers to the competent authorities in the Member States. Despite the principle of institutional autonomy, ${ }^{16}$ the role of the national legislature is limited to designating the competent authority. The rest follows automatically from the direct applicability of the Regulation.

In most Member States, these competences will be supplemented by competences provided by national law.

According to Article 14 NOCR [11] 'methods and techniques for official controls' shall include (among others): an inspection of: equipment, animals, goods, ingredients, processing aids, traceability, labelling, presentation and hygiene; assessment of procedures, examination of documents, verification of measurements and test results, sampling, analyses, and tests.

Another method provided by NOCR [11] is an examination of the controls that operators have put in place and of the results obtained. Controls that operators have put in place, are often performed by independent third parties. The NOCR [11] leaves it open if the results of such controls can only be obtained from the operator or also from the third party.

Official controls may include interrogations. The NOCR [11] speaks in this context of interviews with operators and their staff.

Additionally, the NOCR [11] provides the power to perform 'any other activity required to identify cases of non-compliance'. I cannot help but wonder what it is the Regulation is doing here. From a rule of law perspective, I would very much like to read this provision as referring to other activities as foreseen in national law. However, the phrasing suspiciously looks as if the NOCR [11] grants competent authorities to invent their own powers as they see fit.

\footnotetext{
${ }^{15}$ Art. 9(5) NOCR [11].

${ }^{16}$ See for example: Jans et al. [7].
} 


\subsection{Sampling}

The power to take samples is further elaborated in Articles 34 and 35 NOCR [11]. Samples shall be taken, handled and labelled in such a way as to ensure their legal, scientific and technical validity. ${ }^{17}$ The competent authorities must ensure that operators, whose animals or goods are subject to sampling, analysis, test or diagnosis in the context of official controls, have the right to a second expert opinion, at the operator's own expense. ${ }^{18}$

\subsection{Official controls online}

Inspectors face specific challenges when food is traded online. The NOCR [11] addresses these challenges in two ways. First, BOs are under obligation to keep authorities updated regarding their online activities. ${ }^{19}$ Second, it allows authorities to engage in mystery-shopping. I.e. they can purchase products online, disclosing only afterwards their official identity and the objective to perform an official control. Samples ordered from operators by the competent authorities without identifying themselves may be used for the purposes of an official control. ${ }^{20}$ However, after authorities have taken possession of samples, the operators are informed of this fact and of their right to a second expert opinion. ${ }^{21}$

\subsection{Written records}

When official controls have been performed, this must be recorded in writing. ${ }^{22}$ The written records of every official control have to mention at least: the purpose of the control, the methods applied, the outcome, and if such be the case the actions required from the BO.

Unless the purposes of judicial investigations or the protection of court proceedings require otherwise, the operators subject to an official control shall be provided upon request with a copy. ${ }^{23}$

\subsection{Disclosure of results}

For several years now, a trend can be observed among inspection agencies in the Member States to disclose their findings to the general public, including findings in individual cases. ${ }^{24}$ The NOCR [11] provides general provisions to this effect in Article 11(3) read in conjunction with Article 8(5).

\footnotetext{
${ }^{17}$ Art. 34(5) NOCR [11].

${ }^{18}$ Art. 35(1) NOCR [11].

${ }^{19}$ Art. 15(5) NOCR [11].

${ }^{20}$ Art. 36(1) NOCR [11].

${ }^{21}$ Art. 36(2) NOCR [11].

${ }^{22}$ Art. 13 NOCR [11].

${ }^{23}$ Art. 13(2) NOCR [11].

${ }^{24}$ The European Food and Feed Law Review (EFFL) published a special issue on this topic in 2007 (issue $5)$.
} 
Competent authorities may publish, or make otherwise available to the public, information about the rating of individual operators based on the outcome of one or more official controls, provided that the rating criteria are objective, transparent and publicly available; and appropriate arrangements are in place to ensure the fairness, consistency and transparency of the rating process. ${ }^{25}$

Confidentiality obligations shall not prevent the competent authorities from publishing information about the outcome of official controls regarding individual operators, provided: (a) the operator concerned is given the opportunity to comment and the publication takes these comments into account. ${ }^{26}$

\subsection{Enforcement policy}

The NOCR [11] requires there to be a policy on official controls laid down in plans. ${ }^{27}$ It further provides certain substantive requirements regarding the content of such policies. These requirements relate to investigations and measures to be taken.

According to Article 137(2) NOCR [11], in case of suspicion of non-compliance, the competent authorities shall perform an investigation in order to confirm or to eliminate that suspicion. The way this provision is phrased suggests that the NOCR [11] does not mean to leave the national authorities much discretion in this regard. If it should indeed be read in this way, it does not show much understanding of the realities on the ground. Acting on each and every suspicion will rarely be a viable option.

Once a non-compliance has been established, the competent authorities shall give priority to action to be taken to eliminate or contain risks to human, animal and plant health, animal welfare et cetera. ${ }^{28}$ This suggests that in principle actions/measures (on the basis of Article 138 [11]) come before penalties (on the basis of Article 139 [11]). This is in line with the objective of food law to first and foremost protect human life and health. ${ }^{29}$

\subsection{Actions and penalties}

Responses to non-compliances may differ depending on the objectives pursued by these responses. The purpose may be to solve problems for example by restoring food safety or to punish wrongdoers. Along these lines the current Official Control Regulation [10] distinguishes actions and sanctions. ${ }^{30}$ In the language of the NOCR [11] these are called measures and penalties. However, also the word 'action' is still used. Article 138 NOCR [11] addresses actions/measures to remedy non-compliances and Article 139 NOCR [11] addresses penalties.

\footnotetext{
${ }^{25}$ Art. 11(3) NOCR [11].

${ }^{26}$ Art. 8(5) NOCR [11].

${ }^{27}$ Art. 109 (multi-annual national control plans), Art. 112 (coordinated control programmes), Art. 115 (contingency plans) NOCR [11].

${ }^{28}$ Art. 137(1) NOCR [11].

${ }^{29}$ Art. 5 Regulation 178/2002 [8].

${ }^{30}$ Art. 54 and 55 Regulation 882/2004 [10].
} 


\subsection{Actions in the event of established non-compliance}

Similar to controls, the NOCR [11] is quite strict in setting out what is required from competent authorities when non-compliances are established without granting much discretion. ${ }^{31}$ In such situation they shall take: any action necessary to determine the origin and extent of the non-compliance and to establish the operator's responsibilities; and take appropriate measures to ensure that the operator concerned remedies the non-compliance and prevents further occurrences of such non-compliance.

In other words, it is the responsibility of the operator to remedy the situation. The authorities ensure that operators live up to this obligation.

When deciding which measures to take, the competent authorities shall take account of the nature of that non-compliance and the operator's past record with regard to compliance. All costs are borne by the operators. ${ }^{32}$

\subsection{Measures}

Similar to the controls, the NOCR [11] directly confers powers upon competent authorities by listing the measures they may take.

Article 137(2) [11] reads as follows: '[...] competent authorities shall take any measure they deem appropriate to ensure compliance with the rules referred to in Article 1(2), including, but not limited to, the following'. Again the NOCR [11] seems to provide an open and unrestricted competence base. Ultimately, the Court of Justice of the EU will have to decide if competent authorities - usually belonging to the executive branch in the Member States - can indeed dream up their own instruments or if an attribution in national legislation is required.

The list of specific competences that follows includes among others the following. The CA can order treatments on goods, order the alteration of labels or corrective information to be provided to consumers; restrict or prohibit the placing on the market; order the operator to increase the frequency of own controls; order the recall, withdrawal, removal and destruction of goods, authorise, where appropriate, the use of the goods for purposes other than those for which they were originally intended; order the isolation or closure, for an appropriate period of time, of all or part of the business of the operator concerned, or its establishments, holdings or other premises; order the cessation for an appropriate period of time of all or part of the activities of the operator concerned and, where relevant, of the internet sites it operates or employs; order the slaughter or killing of animals.

\subsection{Recalls}

Among these measures, the order to recall deserves specific attention. ${ }^{33}$ According to Article 19 of Regulation $178 / 2002^{34}$ a food business operator is under obligation

\footnotetext{
${ }^{31}$ Art. 138(1) NOCR [11].

${ }^{32}$ Art. 138(4) NOCR [11].

${ }^{33}$ Art. 138(2)(g) NOCR [11].

${ }^{34}$ Regulation (EC) No 178/2002 [8].
} 
to recall if it "considers or has reason to believe that a food which it has imported, produced, processed, manufactured or distributed is not in compliance with the food safety requirements'. It goes without saying that this obligation is among the requirements that competent authorities can enforce. Is the NOCR merely restating this fact, or is it doing something more?

The relevance of this question has become apparent from a study on the horsemeat scandal. ${ }^{35}$ Does food affected by fraud such as beef spiked with horse come within the ambit of the recall obligation of Article 19 of Regulation 178/2002 [8]? In some Member States this was indeed believed to be the case and a recall was ordered. In other Member States it was believed that this fraud did not constitute a food safety risk and that therefore the issue was not covered by Article 19. No recall was ordered. Yet other Member States followed the same reasoning, but did order a recall on the basis of an additional competence available in national legislation. It can be argued that the NOCR [11] provides such an additional competence to order a recall in case of non-compliances not covered by Article 19 of Regulation 178/2002 [8].

\subsection{Penalties}

Regarding penalties, the NOCR [11] takes a different approach than regarding controls and measures. The NOCR [11] does not provide the competence to impose penalties but merely reiterates the requirement of Article 17(2) of Regulation 178/2002 [8] that Member States should have penalties in place in their national law and that these should be 'effective, proportionate and dissuasive'. ${ }^{36}$

The NOCR [11] provision at issue contains a curious mistake by stating 'Member States shall lay down the rules on penalties applicable to infringements of this Regulation and take all measures necessary to ensure that they are implemented.' 'This Regulation' is the NOCR [11]. The NOCR, however, imposes only few obligations on operators, such as the obligation to cooperate. ${ }^{37}$ Most obligations are on authorities. Are we to understand that the NOCR [11] mandates Member States to submit their own competent authorities to penalties? Elsewhere, even in the second paragraph of the same Article, reference is made to: 'violations of this Regulation and of the rules referred to in Article 1(2).' Article 1(2) [11] lists all the areas of law to which the NOCR [11] applies. What is mentioned in neither paragraph are the orders given on the basis of Article 138 [11] and the other actions and measures mentioned in that provision. Including these in Article 139 [11] would have made a whole lot of sense as it certainly would have added 'bite' to these measures.

The NOCR [11] then goes on to require that Member States shall ensure that financial penalties for violations perpetrated through fraudulent or deceptive practices, reflect, in accordance with national law, at least either the economic advantage for the

\footnotetext{
${ }^{35}$ See: Sofie van der Meulen et al. [24].

${ }^{36}$ Art. 139(1) NOCR [11].

${ }^{37}$ See Sects. 3.3 and 4.2 .
} 
operator or, as appropriate, a percentage of the operator's turnover. EU wide we now see increases in the level of penalties. ${ }^{38}$

\section{The position of business operators}

\subsection{Responsibility}

According to Article 17(1) of the General Food Law, ${ }^{39}$ operators are responsible to ensure that foods or feeds satisfy the requirements of food law which are relevant to their activities and shall verify that such requirements are met. From the history of this provision, it is clear that the legislature intended to rearrange the relation between businesses and inspectors: ${ }^{40}$

'In some areas of European food law, notably in hygiene legislation, the primary responsibility for ensuring compliance with food law, and in particular the safety of the food, rests with the food business. To complement and support this principle there must be adequate and effective controls organised by the competent authorities of the Member States. In other areas of food law this principle is not so widely applicable. This proposal will extend this principle to all food law, and lead to a general review of food law to establish if this principle is respected or whether there are rules where Community legislation has unnecessarily taken responsibility away from the feed or food business by prescribing how a given objective has to be achieved instead of fixing the objective.'

Ideally, food legal requirements should be framed in such a way that businesses can decide how to achieve the objectives of safety. They can then be held to account for the results. In relation to hygiene self-regulation, the extent of businesses' autonomy towards inspectors has been put to the test of the Court of Justice of the EU (CJEU).

Austrian food safety inspectors acted against businesses that sold bread through self-service. Consumers could take unprepackaged bread out of plastic containers. It was also possible to place bread back into the container after removal. The inspectors considered this practice unhygienic and fines were imposed. The Austrian court dealing with the case referred preliminary questions to the CJEU. The Austrian court wished to know whether a food is unfit for consumption where a foodstuff offered for sale could conceivably have been touched or sneezed upon by a would-be purchaser. The EU Court neatly analysed on the basis of responsibility: ${ }^{41}$

'It follows that, in a situation such as that in the main proceedings, where the competent authorities do not appear to have concluded that there was actual

\footnotetext{
${ }^{38}$ For Italy and the Netherlands, see Corini/Van der Meulen [1], See also (in German), Van der Meulen [18].

${ }^{39}$ Regulation 178/2002 [8].

${ }^{40}$ European Commission [4], p. 10-11.

${ }^{41}$ Case C-382/10 Albrecht a.O. v Landeshauptmann von Wien, EU:C:2011:639, para. 22.
} 
contamination, it cannot be concluded that food business operators have infringed the abovementioned paragraph 3 [of Chap. IX of Annex II to Regulation (EC) No 852/2004 [9]] on the basis only of the finding that a potential purchaser could conceivably have touched the foodstuffs by hand or sneezed on them, without considering the measures taken by those operators under Article 5 of the regulation [852/2004 [9]] in order to prevent, eliminate or reduce to acceptable levels the hazard which the contamination referred to in paragraph 3 of Chap. IX of Annex II to the regulation [852/2004 [9]] may present and without determining that the measures taken in that regard were insufficient in the light of all the available relevant data.'

The essence is in the last sentence of this quote. In assessing compliance, the inspector has to take account of the measures taken by the business to implement its obligations. This finding is of crucial importance. In this situation of imposed selfregulation under food hygiene law, the self-made requirements are the ones against which compliance has to be assessed. Inspectors cannot simply override the selfregulatory system by their own assessment of what the hygiene situation requires. ${ }^{42}$

\subsection{Obligations to cooperate}

Generally, all establishments of food businesses must be registered. ${ }^{43}$ In addition, the NOCR [11] places operators under obligation to provide the competent authorities with updated details on their name and legal form; and the specific activities they carry out, including activities undertaken by means of distance communication (i.e. through the Internet), and the places under their control. ${ }^{44}$

The NOCR [11] obliges operators confronted with official controls to provide access to premises, places, means of transport, to computerised information management systems, to animals and goods, and to documents and information. ${ }^{45}$

During official controls and other official activities, operators shall cooperate with and assist the staff of the competent authorities in the accomplishment of their tasks. ${ }^{46}$ This requirement may include the obligation to provide answers when interviewed.

\subsection{Right to remain silent?}

Although absent in the EU charter and in the European Convention on Human Rights and Fundamental Freedoms (ECHR), it is generally considered a human right not to incriminate oneself and to remain silent in a criminal investigation. In face of the farreaching obligations to cooperate and the severe sanctions facing business operators who have committed infringements, one would have expected the NOCR [11] to be clear either about the limits to the obligation to cooperate, or about limits to punitive

\footnotetext{
${ }^{42}$ On the concept of responsibility, see: Van der Meulen [21] and Van der Meulen [22].

${ }^{43}$ Art. 6 of Regulation 852/2004 [9].

${ }^{44}$ Art. 15(5) NOCR [11].

${ }^{45}$ Art. 15(1)(a)-(d) NOCR [11].

${ }^{46}$ Art. 15(2) NOCR [11].
} 


\section{III-14 Privilege against self-incrimination and (legal) professional privilege}

(1) Where it is within the responsibility of public authorities to establish a violation of EU law and this violation may lead to an administrative sanction, they are under the obligation to respect a private party's privilege against self-incrimination as well as his or her legal professional privilege.

(2) Where the privilege against self-incrimination or the legal professional privilege referred to in paragraph 1 have been violated in the course of gathering information, the information must not be used as evidence in proceedings by public authorities if this violation of procedural rights could have had an impact on the content of the decision.

Fig. 2 ReNEUAL on the right to remain silent

uses of information obtained under such obligation. However, the NOCR [11] itself exercises a right to remain silent in this regard. In my view, this is disturbing and deeply disappointing. It is all the more disturbing because it is in no way certain that the NOCR [11] leaves discretion to the Member States to include such protection in national legislation.

An example how it could have been regulated is readily available in the 'ReNEUAL Model Rules on EU Administrative Procedure' [12] (see: Fig. 2). This scholarly draft for a codification of EU administrative law has been commissioned by the European Commission and is readily available on the Internet. ${ }^{47}$ It is regrettable that the Commission seems not to have consulted this model when drafting the NOCR [11].

\subsection{Rights of defence}

Despite the lack of a right to remain silent, the NOCR [11] is not totally blind to the rights of defence.

Article 7 NOCR [11] requires that certain decisions under the NOCR [11] are subject to a right of appeal. These decisions include among others the actions in case of non-compliance. Not mentioned are penalties. This is surprising as with regard to penalties - which constitute prosecution within the meaning of Article 6 ECHR remedies are mandatory.

Other rights of defence include the right to comment before the competent authority publishes its findings from the controls performed on the business, ${ }^{48}$ the right to rectification of incorrect publications by the control authority, ${ }^{49}$ the right to request a copy of the written records of controls ${ }^{50}$ and the right to a second expert opinion

\footnotetext{
${ }^{47}$ ReNEUAL Model Rules on EU Administrative Procedure, http://www.reneual.eu/.

${ }^{48}$ Art. 8(5) NOCR [11]. See Sect. 3.7.

${ }^{49}$ Art. 11(2) NOCR [11].

${ }^{50}$ Art. 13(2) NOCR [11]. See Sect. 3.6.
} 
for operators whose animals or goods are subject to sampling, ${ }^{51}$ including sampling online..$^{52}$

\section{The position of witnesses}

The NOCR [11] addresses the position of witnesses in Article 140 [9] on reporting of infringements. According to this provision, Member States shall ensure that competent authorities have effective mechanisms to enable reporting of actual or potential infringements. ${ }^{53}$ These mechanisms must include procedures for the receipt of reports of infringements and their follow-up. ${ }^{54}$

From the perspective of witnesses most important is that the mechanisms must also include appropriate protection for persons reporting an infringement against retaliation, discrimination or other types of unfair treatment; and protection of personal data of the person reporting an infringement (in accordance with Union and national law).

The legislature clearly has whistle blowers in mind, as is also evidenced from Recital 91 [11]:

'Any person should be able to bring new information to the attention of competent authorities which assists them in detecting, and imposing penalties in cases of, infringements of this Regulation and of the rules referred to in Article 1(2). However, whistleblowing could be deterred by the lack of clear procedures or for fear of retaliation. Reporting of infringements of this Regulation is a useful tool to ensure that a competent authority is able to detect and impose penalties for infringements. This Regulation should therefore ensure that adequate arrangements are in place to enable any person to alert the competent authorities to possible infringements of this Regulation and to protect that person from retaliation.'

However, not only people who bring information spontaneously to the attention of authorities are in need of protection. The same may be true for staff members of businesses who are 'interviewed' on the basis of Artocle 14(f) NOCR [11] (as discussed above in Sect. 3.3).

\section{The position of victims and consumers}

The recitals of the NOCR [11] recall that the Treaty on the Functioning of the European Union provides that the Union is to contribute to the attainment of a high level

\footnotetext{
${ }^{51}$ Art. 35 NOCR [11]. See Sect. 3.4 .

${ }^{52}$ Art. 36(2) NOCR [11]. See Sect. 7.2.

${ }^{53}$ Art. 140 NOCR [11] refers to actual or potential infringements 'of this Regulation'. See on the question if this phrasing should be considered a mistake Sect. 3.13.

${ }^{54} \mathrm{~A}$ shortcoming in this regard contributed to the outbreak of the Fipronil-incident in the Netherlands, see: Sorgdrager [13].
} 
of consumer protection ${ }^{55}$ and that consumer confidence must be ensured. ${ }^{56}$ As anywhere else in food law, however, the NOCR [11] does not empower consumers to stand up for their rights in the enforcement arena, not even those consumers who are actually victims of non-compliances. ${ }^{57}$

As indicated above, Article 140 NOCR [11] does require Member States to ensure that competent authorities have effective mechanisms to enable reporting of actual or potential infringements 'of this Regulation'. These mechanisms should include procedures for the receipt of reports of infringements and their follow-up. But beyond this, the NOCR does not ensure that victims have a right to complain about noncompliances affecting them, no right to demand investigation or request enforcement. It does not grant them a right to be heard in an ongoing investigation. It does not provide them access to the file. It does not ensure they are informed of the decision taken let alone the right that a decision will be taken. It does not grant them a right to appeal a decision if it is taken.

In short, the victim, the consumer is nobody in the new OCR [11].

If we are serious about the claim that food law serves to protect the consumer, this has to change. Who knows the needs of consumers better than the consumers themselves?

\section{Capita selecta}

\subsection{Compliance assistance?}

The food sector is in the top three of the most regulated sectors in the EU. Probably, it is the most regulated sector. ${ }^{58}$ However, unlike sectors such as pharmaceuticals and chemicals it consists for $99 \%$ of number of businesses (and about $50 \%$ of turn over) of small and medium sized enterprises. The vast majority of these businesses are probably sincere in their desire to comply with their legal obligations. For many of them, compliance means doing as the inspector tells you to do. ${ }^{59}$

Competent authorities whose inspectors visit businesses on a regular basis, are best placed to help businesses comply. It is right out disappointing that the NOCR [11] does not dedicate one single word to compliance assistance. It seemed an opportunity hard to miss. ${ }^{60}$

\subsection{Fraud}

While work was ongoing on the recast of the Official Controls Regulation, the horsemeat scandal erupted, and EU politics became aware of fraud as an issue worthy of

\footnotetext{
${ }^{55}$ Recital 2 NOCR [11].

${ }^{56}$ Recital 74 NOCR [11].

${ }^{57}$ I elaborated on this in: Van der Meulen [17].

${ }^{58}$ See: Van der Meulen [23].

${ }^{59}$ Van der Meulen [20].

${ }^{60}$ Indeed, in the context of the Food Safety Modernization Act, the USA places great emphasis on compliance assistance.
} 
attention. At hindsight this has been a blind spot in the food legal system as it was developed in the early 2000s. Its problem definition focussed on microorganisms and toxic substances. ${ }^{61}$ It was less aware of the human factor. ${ }^{62}$ This has been remedied in the NOCR [11].

The new awareness of fraud has affected the drafting processes and some provisions have been included in the NOCR [11]. These provisions consistently refer to 'fraudulent or deceptive practices'. The NOCR [11] does not provide any definition or other clarification of these concepts. The choice of concepts and the lack of delineation are sure to contribute to complications in enforcement and litigation. After all, which evidence needs to be provided to show that fraud or deception has taken place? These complications could easily have been avoided. The only thing that matters in case of non-compliance with agri-food law is whether beyond its undesired effect, it can be shown to have occurred intentionally or through gross negligence. Intent and negligence are well known and well-defined legal concepts. Everything the legislature wanted to achieve, could have been achieved by choosing these concepts rather than 'fraudulent or deceptive practices'.

The special attention to "fraudulent or deceptive practices" covers the scope of the regulation, the setting of controls priorities and the level of penalties. Furthermore, there is an institutional element in the designation of European Union reference centres for the authenticity and integrity of the agri-food chain. ${ }^{63}$ However, institutional aspects are not covered in this article.

According to Article 1(4) NOCR [11] the Common Agricultural Policy is outside the scope of the Regulation, 'however, this Regulation shall apply to checks pursuant to Article 89 of Regulation (EU) No 1306/2013, where those checks identify possible fraudulent or deceptive practices in respect of the marketing standards [... ]'. According to Article 9(2) '[c]ompetent authorities shall perform official controls regularly, with appropriate frequencies determined on a risk basis, to identify possible intentional violations of the rules referred to in Article 1(2), perpetrated through fraudulent or deceptive practices'. Finally, Article 139(2) NOCR [11] states: 'Member States shall ensure that financial penalties for violations of this Regulation and of the rules referred to in Article 1(2), perpetrated through fraudulent or deceptive practices, reflect, in accordance with national law, at least either the economic advantage for the operator or, as appropriate, a percentage of the operator's turnover.'

\subsection{Enforcement online}

The NOCR [11] takes the new virtual realities into account in the obligations of operators, powers of official controls and measures in case of noncompliance. Operators must keep authorities updated on their online activities. ${ }^{64}$ Competent authorities can perform official controls through mystery shopping online. ${ }^{65}$ Among the mea-

\footnotetext{
${ }^{61}$ Van der Meulen [19].

${ }^{62}$ Corini [2].

${ }^{63}$ Art. 97 NOCR [11].

${ }^{64}$ Art. 15 NOCR [11].

${ }^{65}$ Art. 36 NOCR [11].
} 
sures competent authorities have at their disposal to deal with non-compliances, is the closing of internet sites. ${ }^{66}$

\subsection{Private certification schemes}

Private food law is on the rise. ${ }^{67}$ Increasingly powerful key players in the food chain require their business partners to follow private standards and engage third party audits and certification. This new reality is reflected in the NOCR [11]. On the one hand 'the reliability and results of own controls that have been performed by the operators, or by a third party at their request, including, where appropriate, private quality assurance schemes, for the purpose of ascertaining compliance' is taken into account in the setting of risk-based priorities for official controls. ${ }^{68}$ On the other hand 'an examination of the controls that operators have put in place and of the results obtained' is included in the methods and techniques of official controls available to the competent authorities. ${ }^{69}$ As discussed above in Sect. 3.3 at present it is unclear whether the results of private controls can only be accessed through the operator subject to the official control, or also from the third party. Obviously, the national legislature can submit third parties to an obligation to cooperate. However, it may require a ruling from the CJEU to establish beyond dispute if this is already included directly in the NOCR [11].

\section{Discussion}

A codification of administrative law at EU level is lacking. The expansion of the rules on official controls through Regulation (EU) 2017/625 [11] to cover almost the entire agri-food sector may represent an important bottom-up step towards such codification.

Dear reader, while the objective of this article is mainly to paint the big picture of the new regulation on official controls, allow me to conclude by providing my personal opinions and observations for the purpose of discussion.

The balance in attention dedicated to and in legal position granted to public authorities, to businesses subject to enforcement, to witnesses, to victims and to consumers in general can still be much improved. Everywhere in food law we perceive the legislature's mindset to aim to protect consumers from harm to health and life with less attention to empowerment, rights and justice.

This mindset may in part be explained by the involvement of scientific experts in the fields of food and health who know better what is good for consumers than consumers know themselves. Awareness of the right to food ${ }^{70}$ or of values typical for

\footnotetext{
${ }^{66}$ Art. 138(2) NOCR [11].

${ }^{67}$ Van der Meulen et al. [15].

${ }^{68}$ Art. 9(1)(d) NOCR [11]. See Sect. 3.2.

${ }^{69}$ Art. 14(a) NOCR [11]. See Sect. 3.3.

${ }^{70}$ As recognised, for example, in the International Covenant on Economic Social and Cultural Rights [6] - to which all EU Member States are state parties.
} 
lawyers such as civil liberties, rule of law and human rights is scarce in food law. ${ }^{71}$ If we wish to increase awareness of and respect for such values in EU agri-food law, lawyers should make it their responsibility to involve themselves in the debates and the legislative work.

As long as democracy and rule of law are not firmly rooted in every EU Member State, the EU legislature should not endow national executive authorities with open ended powers to perform 'any [...] activity required to identify cases of noncompliance' and to undertake 'any action necessary to determine the origin and extent of the non-compliance and to establish the operator's responsibilities'.

Responsibilities of competent authorities should not be limited to controlling, correcting and sanctioning. They should also be required to provide compliance assistance to those businesses who earnestly seek to comply.

It is laudable that the Regulation ensures some rights of defence for operators subject to controls and sanctions. These rights should be further aligned to Article 6 ECRM. Limits to the obligation to cooperate should be defined either through recognition of a right to remain silent for protection against self-incrimination or by excluding information obtained through such obligation from being used to impose penalties. Penalties should be fully covered by the right to appeal.

All witnesses should enjoy protection from retaliation, not only those actively engaging in whistleblowing.

Victims should be granted full access to procedures, to the files, to decisions and to legal remedies.

Consumers should be recognised as stakeholders and actors in food law. They should be empowered both collectively and individually.

Open Access This article is distributed under the terms of the Creative Commons Attribution 4.0 International License (http://creativecommons.org/licenses/by/4.0/), which permits unrestricted use, distribution, and reproduction in any medium, provided you give appropriate credit to the original author(s) and the source, provide a link to the Creative Commons license, and indicate if changes were made.

\section{References}

1. Corini, A.A., Van der Meulen, B.M.J.: Regulating food fraud: public and private law responses in the EU, Italy and the Netherlands. In: Gray, A., Hinch, R. (eds.) A Handbook of Food Crime. Immoral and Illegal Practices in the Food Industry and What To Do About Them. Policy Press, Bristol (2018)

2. Corini, A.A.: Food Law Enforcement in the EU. Public Powers and Private schemes to deal with Food Law infringements. PhD thesis. https://www.berndvandermeulen.eu/food-law-enforcement.html (2018)

3. Corini, A.A., Van der Meulen, B.M.J., Kets, F., Ottimofiori, G., Blanc, F.: Enforcement of EU food law. In: Scholten, M., Luchtman, M. (eds.) Law Enforcement by EU Authorities. Implications for Political and Judicial Accountability. Elgar, Cheltenham Glos (2017)

4. European Commission, Proposal for a Regulation of the European Parliament and of the Council laying down the general principles and requirements of food law, establishing the European Food Authority, and laying down procedures in matters of food, 8.11.2000, $\mathrm{COM}(2000) 716$ final

5. Hyde, R., Savage, A.: Coming together to combat food crime: regulatory networks in the EU. In: Gray, A., Hinch, R. (eds.) A Handbook of Food Crime. Immoral and Illegal Practices in the Food Industry and What To Do About Them. Policy Press, Bristol (2018)

${ }^{71}$ Regarding free speech in relation to food labelling, see: Van der Meulen/Van der Zee [14]. 
6. International Covenant on Economic Social and Cultural Rights

7. Jans, J.H., Prechal, S., Widdershoven, R.J.G.M. (eds.): Europeanisation of Public Law, 2nd edn. Europa Law Publishing, Amsterdam (2015)

8. Regulation (EC) $178 / 2002$ of the European Parliament and of the Council of 28 January 2002 laying down the general principles and requirements of food law, establishing the European Food Safety Authority and laying down procedures in matters of food safety [2002] OJ L 31/1

9. Regulation (EC) 852/2004 of the European Parliament and of the Council of 29 April 2004 on the hygiene of foodstuffs [2004] OJ L 139/1

10. Regulation (EC) 882/2004 of the European Parliament and of the Council of 29 April 2004 on official controls performed to ensure the verification of compliance with feed and food law, animal health and animal welfare rules [2004] OJ L 165/1

11. Regulation (EU) $2017 / 625$ of the European Parliament and of the Council of 15 March 2017 on official controls and other official activities performed to ensure the application of food and feed law, rules on animal health and welfare, plant health and plant protection products [2017] OJ L 95/1

12. ReNEUAL Model Rules on EU Administrative Procedure. http://www.reneual.eu/

13. Sorgdrager, W.: Rapport Commissie onderzoek Fipronil in eieren, For the official report and a very short summary in English. https://www.berndvandermeulen.eu/agri-food.html

14. Van der Meulen, B.M.J., Van der Zee, E.: "Through the Wine Gate" First Steps towards Human Rights Awareness in EU Food (Labelling) Law. EFFL 8/1/2013, 41-52

15. Van der Meulen, B.M.J. (ed.): Private Food Law: Governing Food Chains Through Contract Law Self-Regulation, Private Standards, Audits and Certification Schemes. Wageningen Academic, Wageningen (2011). http://www.wageningenacademic.com/doi/book/10.3920/978-90-8686-730-1

16. Van der Meulen, B.M.J., Corini, A.A.: Food Law enforcement in the EU. Administrative and private systems. In: Nieto Martin, A., Quackelbeen, L., Simonato, M. (eds.) Food Regulation and Criminal Justice. Maklu, Antwerp (2017)

17. Van der Meulen, B.M.J.: Consumer. For you, about you, over you, without you. In: Van der Meulen, B.M.J. (ed.) EU Food Law Handbook. Wageningen Academic, Wageningen (2014)

18. Van der Meulen, B.M.J.: Durchsetzung des EU-Lebensmittelrechts in den Mitgliedstaaten: Die Beispiele "Medizinische Claims" und "Pferdefleischskandal" als Aufforderung zur Schaffung eines horizontal vergleichenden EU-Lebensmittelrecht. Härtel, I. (ed.): Wege der Ernährungswirtschaft global, regional, europäisch. Nomos, Glashütte (2017)

19. Van der Meulen, B.M.J.: Is current EU food safety law geared up for fighting food fraud? J. Consum. Prot. Food Saf.. 10, 19-23 (2015). https://doi.org/10.1007/s00003-015-0992-2

20. Van der Meulen, B.M.J.: Reconciling Food Law to Competitiveness. European Institute for Food Law Series, vol. 3. Wageningen Academic, Wageningen (2009). http://www.wageningenacademic.com/ doi/book/10.3920/978-90-8686-679-3

21. Van der Meulen, B.M.J.: Responsibility in EU food law. In: Verbruggen, P., Havinga, T. (eds.) Hybridization of Food Governance. Trends, Types and Results. Elgar, Cheltenham Glos (2017)

22. Van der Meulen, B.M.J.: Symbiotic food law: reflection on the role of responsibility. working paper. http://ssrn.com/abstract=2479294

23. Van der Meulen, B.M.J.: Systematic analysis of food law. In: Van der Meulen, B.M.J. (ed.) EU Food Law Handbook. Wageningen Academic, Wageningen (2014)

24. Van der Meulen, S., Boin, G., Bousoula, I., Conte-Salinas, N., Paganizza, V., Montanari, F., Rodriguez Fuentes, V., Van der Meulen, B.M.J.: Fighting food fraud. Horsemeat scandal; use of recalls in enforcement throughout the EU. EFFL 2015, 1-12

25. Van der Veer, L.C.: Food online. PhD thesis, Lexxion (2017) 